\title{
WAHHABISM, IDENTITY AND SECULAR RITUAL: Graduation at an Indonesian High School
}

\section{Inayah Rohmaniyah}

Indonesian Consortium for Religious Studies (ICRS), Yogyakarta, Indonesia

\section{Mark Woodward}

Arizona State University, USA

\section{Abstract}

This paper concerns the social and ritual construction of social identities at Pondok Pesantren Madrasah Wathoniyah Islamiyah (PPMWI), a theologically Wabhabi oriented pesantren (traditional Islamic school) in Central Java, Indonesia. We focus on the inter-play of religious and secular symbols in the school's graduation ceremonies (wisuda) for secondary school students and the ways it contributes to the construction of individual and social identities. Our analysis builds on Turner's studies of the processual logic of rites of passage, Moore and Meyerhoff's distinction between religious and secular ritual and Tambiab's application of the Piercian concept of indexical symbols to the analysis of ritual. Theoretically we will be concerned with ritual, cognitive and social processes involved in the construction of religious identities. Empirically, we critique the common assumption that Salafi, and more specifically, Wabhabi, religious teachings contribute to the construction of exclusivist identities, social conflict and violence. In the case we are concerned with, religious tolerance and non-violence are among the defining features of Wahhabi identity.

[Tulisan membahas konstruksi identitas ritual dan sosial pada sebuah pesantren yang berorientasi teologi Wabhabi, yaitu Pondok Pesantren Madrasah Wathoniyah Islamiyah (PPMWI). Diskusi akan difokuskan pada saling silang simbol-simbol agama dan sekuler dalam peringatan 
wisuda siswa menengah pertama serta signifikansinya dalam konstruksi identitas sosial dan individual. Analisis tulisan ini berdasarkan studi Turner mengenai logika proses dalam daur ritus (the processual logic of rites of passage), pembagian ritual agama dan sekuler oleh Moore dan Meyerhoff serta konsep Piercian mengenai indek simbolis dalam ritual oleh Tambiah. Secara teoritis, artikel ini akan mendiskusikan ritual, kognisi, dan proses sosial yang menjadi bagian dalam konstruksi identitas agama. Selain itu, penulis juga melakukan kritik terbadap pandangan umum mengenai Wabhabi yang dituduh sebagai identitas ekslusif, biang-kerok konflik sosial dan kekerasan. Penulis menemukan sebaliknya, bahwa toleransi antar agama dan anti-kekerasan adalah salah satu ciri identitas Wabhabi.]

Keywords: Wahhabi, PPMWI, identity

\section{A. Introduction: Constructing Social Identities}

There is a fundamental distinction between primordialist and constructivist approaches to the study of ethnic, religious and other social identities. Primordialist approaches assume that social identities are based on principles that endure over time and are extremely resistant to change. Constructivisms share the view that change is a basic feature of culture and religion. In a review of the literature on identity and ethnic violence Fearon and Laitin contrast primordialist and constructivist approaches and conclude that the former have limited explanatory power. ${ }^{1}$ They distinguish between three constructivist approaches: The first emphasizes the logic of cultural and discursive systems, the second elite manipulation and the third the manipulation and construction of difference by "on the ground" social groups. They also note that despite the currency of the concept of the "social construction of identity" that there are few case studies focusing on the nature of the process. One reason for the absence of detailed case studies is that research by political scientists tends to be conducted at the macro-level focusing on the interaction groups engaged in national or regional level conflict and that conducted by social psychologists relies on laboratory experiments. Our research is situated between these poles in intellectual territory demarcated by

${ }^{1}$ D. Fearon and D, Laitin, "Violence and the Social Construction of Ethnic Identity," International Organization, vol. 54, no. 4, Autumn 2000, pp. 845-877. 
Barth, Lehman and other anthropologists concerned with the social construction of ethnic categories. ${ }^{2}$ By focusing on a smaller, sub-ethnic religious community, we provide insight into the ways in which social identities are constructed in natural environments. We show that the constructivist approaches Fearon and Laitin describe are not mutually exclusive and argue that social identities emerge from the cognitive process Lévi-Strauss describes 'bricolage.'

The French term bricolage referred originally to unforeseen events and subsequently to objects produced by craftsmen working with readily available tools and materials at. Lévi-Strauss uses it to describe processes through which abstract structural principles, or what Sperber would later call "symbolic knowledge," 3 are used in the interpretation of nature and social relations and the construction of mythological narratives. He describes the process as follows:

The characteristic feature of mythological thought is that it expresses itself by means of a heterogeneous repertoire, which, even if extensive, is never the less limited. It has to use this repertoire, however, whatever the task in hand because it has nothing else at its disposal. Mythological thought is therefore a kind of intellectual 'bricolage'-which explains the relation which can be perceived between the two. Like bricolage of the technical plane, mythical reflection can reach brilliant unforeseen results on the intellectual plane. ${ }^{4}$

Jenkins argues that social identities define groups by identifying commonality and by referencing categories of otherness. ${ }^{5}$ Here we argue that bricolage is among the means through which both are constructed and that ritual is among the means through which it operates. It is also among the social contexts in which individuals internalize the narratives, symbols and doctrines used by elites to define collective identities. The

${ }^{2}$ F. Barth, Ethnic Groups and Boundaries. The Organization of Culture Difference (Long Grove: 1998 [1969]); F. Lehman, "Kayah Society as a Function of the Shan-BurmeseKaren Context," Contemporary Change in Traditional Societies, volume I. Steward, J. (ed.) (Urbana: University of Illinois Press, 1967), pp. 1-104.

${ }^{3}$ D. Sperber, Rethinking Symbolism (Cambridge: Cambridge University Press 1975), pp. 91-105. p. 117.

${ }^{4}$ C. Levi Strauss, The Savage Mind (Chicago: University of Chicago Press, 1966),

${ }^{5}$ R. Jenkins, Social Identities (London: Routledge, 2004), pp. 85-87. 
distinction that Fearon and Laitin make between elites and "on the ground" social groups is also relative. With respect to students and their families, the pesantren's religious leaders are elites, but in relationship to the larger society, the pesantren community is a social group.

\section{B. Muslim Schools, and Religious Movements in Southeast Asia}

Pesantren are traditional Javanese Muslim schools. Originally they offered only religious education. Many began to teach secular subjects to offer an alternative to schools established by Christian missionaries and colonial governments in the early decades of the twentieth century. Schools teaching a combination of religious and secular subjects have figured significantly in the definition of Muslim communities in Indonesia and elsewhere in Muslim Southeast Asia since the late nineteenth century. ${ }^{6}$ They have been vehicles for the dissemination of modernist and fundamentalist theologies originating in Egypt and Arabia and for the modernization of traditional Islam. ${ }^{7}$ Schools have also played important roles in the development of Muslim social movements and of which the Indonesian modernist Muhammadiyah and traditionalist Nadhlatul Ulama (Renaissance of the Muslim Scholars - NU) are by far the largest. Today, there are at least 17,000 pesantren, most of which are affiliated with NU in some way. ${ }^{8}$ There are, however, others, including

${ }^{6}$ For an overview of Islamic education in Southeast Asia see: R. Hefner (ed.), Making Modern Muslims. The Politics of Education in Southeast Asia (Honolulu: University of Hawai'i Press, 2009). On pesantren see: Z. Dhofier, The Pesantren Tradition: The Role of the Kyai in the Maintenance of Traditional Islam in Java (Tempe: Arizona State University Program for Southeast Asian Studies Monograph Series, 1999) and M. Woodward, A. Amin, I. Rohmaniyah and D. Coleman "Muslim Education, Celebrating Islam and Having Fun as Counter-Radicalization Strategies in Indonesia," Perspectives on Terrorism, vol. 4, no. 4, 2010, pp. 28-50.

${ }^{7}$ The efforts of modernists with neo-fundamentalist religious orientations to introduce modern education are well known. Those by traditionally oriented Muslim leaders and organizations have received less attention in the academic literature. R. Hefner, "Islamic Schools, Social Movements, and Democracy in Indonesia," in R. Hefner (ed.), Making Modern Muslims. The Politics of Islamic Education in Southeast Asia (Honolulu: University of Hawai'i Press, 2009), pp. 55-105.

${ }^{8}$ On Muhammadiyah see: M. Nakamura, The Crescent Rises Over the Banyan Tree: A Study for the Muhammadiyah Movement in an Indonesian Town (Athens: Ohio University Press, 1983); J. Peacock, Muslim Puritans, Reformist Psychology in Southeast Asia (Berkeley: University of California Press, 1978) and on NU, G. Barton, and G. Fealy (eds), Nadblatul 
PPMWII that are not associated with larger organizations. ${ }^{9}$

Sociologically, the charismatic authority of the kyai distinguishes pesantren from other Islamic schools, including those operated by Muhammadiyah. The kyai is the undisputed authority around which life in a pesantren revolves. His status is often compared with that of a raja (king) in a traditional Javanese state. A kyais authority is based on a combination of Islamic learning, acquired and inherited charisma. Most Javanese kyai are members of a single extended family descending from the Prophet Muhammad and from the legendary Wali Songo (nine saints) who were instrumental in establishing Islam as the religion of Java in the fifteenth century. ${ }^{10}$ There are very few kyai who are not part of this sacred lineage.

Kyai are thought to be sources of blessing (barakab) as well as knowledge. The bond between kyai and santri (students) is such that when asked to name an important religious authority, many Javanese Muslims reply with "my kyai." People come to them to find healing and for advise on topics ranging from marriage and other important life choices, and even what to name their children. It is customary for students to kiss a kyai's hand on greeting him or to touch his sleeve in hope of securing blessing through physical contact. Even the dishes from which he has eaten and the water with which he performs ablutions is thought to be holy. Kyai families are widely regarded as aristocrats and as holy families. Their wives (nyar), sons (gus), daughters (ning) and even grandchildren of prominent kyai are also treated with respect and deference.

A broad distinction can be drawn between schools linked to NU (and similar ones elsewhere in Southeast Asia) and those associated with modernist/fundamentalist orientations such as Muhammadiyah in Indonesia and the Kaum Muda (Young Group) movement in Malaysia

Ulama, Traditional Islam and Modernity in Indonesia (Clayton: Monash Asia Institute, 1996).

${ }^{9}$ On pesantren other than those associated with NU see M. van Bruinessen "Traditionalist and Islamist Pesantren in Contemporary Indonesia," in F. Noor, Y. Sikand and M. van Bruinessen (eds), The Madrasa in Asia: Political Activism and Transnational Linkages (Amsterdam: University of Amsterdam Press, 2009), pp. 217-247.

${ }^{10}$ On the Wali Songo see A. Gade, "Sunan Ampel of the Javanese Wali Songo" in J. Renard, Tales of God's Friends: Islamic Hagiography in Translation (Berkeley: University of California Press, 2009), pp. 341-358. On the importance of kinship as a factor in religious leadership in Java see: Z. Dhofier, "Kinship and Marriage among the Javanese Kyai," Indonesia, vol. 29, 1980, pp. 47-58. 
and Singapore. ${ }^{11}$ In both instances the combination of "modern" subjects including science, technology, European languages and more recently the social sciences and religious ones, especially Quranic exegesis (tafsir), Islamic jurisprudence ( $f i q h)$, has been a driving force in the development of Islamic education.

The theological differences dividing "traditional" and "modernist" schools and associated Muslim movements are, however, enormous and irreconcilable. Traditional Southeast Asian Islam is deeply rooted in sufism (Islamic mysticism) and in the charismatic authority of saints, sultans and kyai (scholar-teachers.) ${ }^{12}$ It is characterized by devotional practices focusing on wasilah (intercession with God) including pilgrimage to the graves of saints (ziarah) and prayers for the dead (tablilan) in addition to the universally acknowledge pillars of the faith including the five daily prayers, fasting during the month of Ramadan and pilgrimage to Mecca. Modernist Islam is influenced by Salafi teachings that reject the notion of wasilah and ritual practices associated with it and acknowledge only what Geertz terms “scripturalist" authority, the Qur'an and hadith. ${ }^{13}$ These theological differences lead to the construction of distinctive identities. Modernists understand themselves to have an unmediated relationship with God and to be entirely responsible for their own salvation. Traditionalists on the other hand have a more collectivist view of religion and in which individuals are related to God through intermediaries including saints and teachers and the collective agency of their fellow Muslims.

PPMWI differs from NU based pesantren because it is based on Salafi and more specifically Wahhabi religious teachings. It differs from Muhammadiyah and other modernist schools because it is based on the charismatic authority of a kyai family though without the mystical understanding of their authority common in NU pesantren. Wahhabism

${ }^{11}$ On this distinction see: T. Abdullah, Schools and Politics. The Kaum Movement in West Sumatra (1927-1933) (Ithaca: Cornell University Press, 1971), pp. 57-84; R. Hasim, Educational Dualism in Malaysia: Implications for Theory and Practice (Kuala Lumpur: Oxford University Press, 1996), pp. 5-36 and D. Noer, The Modernist Muslim Movement in Indonesia, 1900-1942 (Oxford: Oxford University Press, 1973), pp. 101-115.

${ }^{12}$ M. Woodward, Java, Indonesia and Islam (New York: Springer, 2011), pp. 118-121.

${ }^{13}$ C. Geertz, Islam Observed: Religious Development in Morocco and Indonesia (Chicago: University of Chicago Press, 1971), pp. 56-90. 
is a form of Salafism based on the teachings of Muhammad Ibn Abd al-Wahhab (1703-1792) whose thinking was derivative of that of the 13th -14th century jurist Ibn Tamiyyah (1263-1328). ${ }^{14}$ It emphasizes literal, rather than metaphorical or contextual, readings of the Qur'an and hadith (traditions concerning the words and deeds of the Prophet Muhammad) and uncompromising interpretation of the Islamic principle of tawhid (the unity or oneness of God). In Western and Indonesian Salafism and especially Wahhabism are commonly associated with violence, intolerance, bigotry and misogyny and with the imagination of the de-culturized, ahistorical and neo-fundamentalist Islam Roy describes as characteristic of the transnational social movement he refers to as the "New Global Ummah." 15

To understand the variety of Salafisms it is, however, necessary to distinguish between those that reject local cultures and associate Islamic "purity" the Arab, and particularly Saudi Arabian social and cultural practices and others that combine Wahhabi or other Salafi religious teachings with them. ${ }^{16}$ We refer to the former as "domesticated" and the later as "Saudi" Salafism. PPMWI is based on an Indonesian nationalist domesticated Salafism.

\section{Pondok Pesantren Madrasah Wathoniyah Islamiyah (PPMWI)}

PPMWI is located in Kebarongan, Banyumas in the province of Central Java. It is a mid sized pesantren with approximately 1,500 students. ${ }^{17}$ It was founded by Kyai Habib Muhammad, a member of a

${ }^{14}$ On Wahhabi religious teachings see: M. Cook, Commanding Right and Forbidding Wrong in Islamic Thought (Cambridge University Press, 2001), p. 165-191 and De LongBas, Wabhabi Islam: From Revival and Reform to Global Jihad (New York: Oxford University Press, 2004), p. 41-92.

${ }^{15}$ The assumption that Wahhabism is linked with violence is common in both Western and Indonesian discourse. See: D. Gold, Hatred's Kingdom: How Saudi Arabia Supports the New Global Terror (Washington DC: Regency Publishing, 2003), p. 89-124. Indonesian examples include: Saidiman, “The Wahhabis Inferiority," Jaringan Islam Liberal, http://islamlib.com/en/article/the-wahhabis-inferiority/ (accessed 03/26/2010). A. Wahid (ed.), Ilusi Negara Islam. Expansi Gerakan Islam Transnasional di Indonesia (Jakarta: LibForAll Foundation, 2009), p. 59-132.

16 M. Woodward, Muslim Education, p. 36-38.

${ }^{17}$ Some pesantren have only a handful of students. Pondok Pesantren Lirboyo in Kediri, East Java is the largest with more than 20,000. 
well established kyai family, in 1878. He studied at Pesantren Somalangu in neighboring Kebumen and then for more than two decades in Mecca before founding the pesantren that would become PPMWI. ${ }^{18}$ It was originally a traditional pesantren at which there were only male students and that taught only religious subjects. Girls were accepted as students in the early twentieth century when formal education for girls was rare.

The pesantren has been strongly nationalist since the early twentieth century. It was associated with the first Indonesian Muslim nationalist movement Sarekat Islam (founded 1912), several of whose leaders including Tjokroamintono and Agus Salim, visited Kebarongan to meet with its kyai. ${ }^{19}$ Kyai Abdullah Zawawi, one of Kyai Habib's sons established a local branch of Sarekat Islam. He also transformed the pesantren along modernist lines, introducing formal classes and a modern curriculum for which Indonesian, the language of nationalism, not Javanese, the language of culture, or Arabic, the language of religion was the medium of instruction in 1916. The modern curriculum also included Dutch, the language of colonialism. By 1930 it was attracting students from throughout Java and from British Malaya and Singapore. ${ }^{20}$ During the Japanese occupation (1942-1945) and the Indonesian Revolution (1945-1949) members of the pesantren community were actively involved in anti-colonial struggles. Unlike many other kyai, those at PPMWII did not become deeply involved in postcolonial Indonesian politics, choosing instead to concentrate on the school's teaching mission.

When and how the pesantren acquired its Wahhabi orientation is uncertain because there is no documentary evidence. There are three bodies of oral tradition that agree on the nature of the process, but not on the date or the kyai responsible for taking this step. All mention a

${ }^{18}$ Pesantren Somalangu was established by Syech As-Sayyid Abdul Kahfi Al Hasani, a Hadrami (Yemini) sayyid (descendant of the Prophet Muhammad) who came to Java from Syriain 1475. He was associated with two of the Wali Songo, Sunan Ampel and Sunan Kudus. Kyai Habib's wife was one of the Syech's descendants. This locates PPMWI in one of the oldest and most distinguished kyai families in Java.

${ }^{19} \mathrm{~L}$. Assyakanie, Islam and the Secular State in Indonesia (Singapore: Institute for Southeast Asian Studies, 2009), p. 37-42 and R. Van Neil, The Emergence of the Modern Indonesian Elite (The Hague: W. van Hoeve, 1960), pp. 290-295.

${ }^{20}$ Indonesian pesantren, modernist Muslim schools and salafi madrasa continue to attract students from Malaysia and Singapore because government regulation of religion in those countries restricts the range of Muslim education available. 
kyai who left rural Banyumas for a center of Muslim learning, "returned with tawhid" and established it as the school's guiding principle. One attributes this step to Kyai Habib. We think that this is unlikely because Javanese Islam was overwhelmingly sufi in the nineteenth century. The second is that Kyai Habib sent three of his sons to study in Mecca early in the twentieth century. Two of them returned as sufis but the third, Kyai Abdullah Zawawi, brought tawhid to Banyumas. He succeeded his father as kyai while his two brothers established their own pesantren. The third attributes the transformation to Kyai Asifuddin Zawawi, the youngest son of Kyai Abdullah Zawawi who discovered tawhid, while living in Batavia (Jakarta) during the Japanese occupation. The second and third variants are equally plausible and are congruent with broader patterns in the development of Indonesian Islamic modernism. Whoever was responsible for this move did not, however, alter the pesantren's Javanese cultural orientation. It is also significant that this theological shift was the result of an internally driven transformation based on traditional patterns of kyai authority. It is in this respect radically different from the Saudi influenced and financed spread of Wahhabi teachings and cultural practices that involved radical breaks with tradition that began in the 1980s.

Today PPMWII is politically nationalist, committed to democratic governance, religious pluralism and gender equity and is as deeply rooted in Javanese Muslim culture as it is in Wahhabi teachings. ${ }^{21} \mathrm{Al}$-Wahhab's understanding of tawhid that makes humans solely responsible for their own actions and denies the possibility of wasilab is the central feature of the pesantren's identity. This places PPMWII at odds with most other pesantren on theological grounds and leads them to reject ritual practices, including pilgrimage to the tomb of the founding kyai that is a central feature of social identity at other pesantren. Indonesian "Saudi Salafis" and modernists organizations including Muhammadiyah share these views. NU interprets tawhid differently, and understands wasilah and associated pilgrimage traditions as being among the essential tenets of Islam. PPMWI holds Wahhabi views on tawhid, but in other respects is

${ }^{21}$ For an analysis of pesantren with similar social and political agendas oriented in traditional sufi understandings of Islamic theology see F. Pohl, Islamic Education and the Public Sphere: Today's Pesantren in Indonesia (Bonn: WaxmannVerlag GmbH, 2009), pp. 117-125. 
similar to NU based pesantren. Continued insistence on the importance of the kyai, which is central to NU and absent in Muhammadiyah is one example. Another is use of the "bedug", a large drum made from a hollowed log to accompany the azan (call to prayer). Every NU pesantren and mosque has a bedug. Muhammadiyah and most other Salafi groups reject it as bid'ah (unacceptable innovation). PPMWII continues many other Javanese Muslim practices, including torch lit processions on the evening before Id al Fitr at the end of Ramadan, asking forgiveness from neighbors, relatives and friends on the morning of the Id, and enjoying popular music that Saudi-Wahhabis find objectionable. That fact that it is "not NU and not Muhammadiyah" is another central component of PPMWII's collective identity.

The pesantren strongly rejects terrorism and other forms of political violence, considering them to be based on misinterpretations of both the Qur'an and Muslim history. Kyai Fata Mu'min, who led the pesantren until his untimely death in June 2012, explained that Wahhabi teachings lead students to develop a strong faith, embrace forbearance, pray sincerely and partake in other forms positive, non-violent conduct. He stressed the point that genuine Wahhabi teachings forbid the harassment or killing of other Muslims. Students discovered engaging in radical political activity are treated in the same way as those found violating other principles of moral order such as drinking alcohol or using drugs. They are expelled. This aspect of PPMWI's collective identity and the individual identities it seeks to foster in students is defined in opposition to the category "Wahhabi-terrorist" that has become a significant theme in Indonesian religious and political discourse.

Students wear uniforms similar to those used in government run secular Indonesian schools. There are several styles, worn on alternate days. One resembles scout uniforms; another is Javanese batik, reflecting the school's nationalist and cultural orientations. Arab style robes (juba) and the "short pants and long beards" for men and niqab (face veils) for women, that have become iconic of Saudi-Wahhabism and Islamism, are nowhere to be seen. Women cover their hair in fashionable ways common for middle class Indonesians. PPMWI makes a clear distinction between religion and culture, including Arab as well as Javanese culture. Culture is, for religious purposes, irrelevant. By default this makes Javanese 
culture normative because the faculty and almost all of the students are Javanese, and the adaptation of Arabic cultural norms unnecessary. It also takes the position that the state does not have the authority or the right to establish an official orthodoxy because to do so would discriminate against citizens of other religious orientations. It is not affiliated with any mass organization or political party. PPMWI also does not engage in takfiri rhetoric (denouncing professed Muslims as non-believers) and maintains cordial relationships with other Muslim, and non-Muslim groups.

Like most pesantren, PPMWI offers a government approved secular curriculum that enables students to sit for university entrance exams. ${ }^{22}$ It also offers the government Islamic curriculum so general as to be acceptable to Muslims of most sectarian orientations and PPMWI's own Islamic curriculum that focuses on Wahhabi treatises on tawhid. It stresses instruction in both Arabic and English.

Fath al-Majid (The Enlightenment of the Glorious), a commentary on al-Wahhab's Kitäb Tawhid (Book of Tawbid) by his son Abdul Rahman bin Hassan al Sheik (1780-1869) is the core of the PPMWI religious curriculum. ${ }^{23}$ Only PPMWI's most senior scholars are permitted to teach this text. They rely exclusively on the Arabic original because they doubt the accuracy of Indonesian translations. Their explanations locate al-Wahhab's understanding of tawhid in an exegetical frame shaped by PPMWI's other foundational principles. The result is an understanding of Islam very different from NU based pesantren and those of other Indonesian groups including the Islamist party, Partai Keadilan Sejahtera (PKS, The Justice and Prosperity Party) and Majlis Mujahidin Indonesia (MMI, Indonesian Jihad Fighter's Council) that rely on this text, but locate it in exegetical frames rooted in combinations of religious exclusivism and political activism derivative of the combination of Saudi-Wahhabi orthodoxy and Muslim Brotherhood activism. ${ }^{24}$ The most important of

${ }^{22}$ On the integration of secular and religious curricula in pesantren see: R.A. Lukens-Bull, Peaceful Jihad: Negotiating Identity and Modernity in Muslim Java (New York: Palgrave Macmillan, 2005), p. 1-24.

${ }^{23}$ Salafis throughout the world consider Fath al-Majid to be an authoritative work.

${ }^{24}$ See: M. Woodward, A. Amin , I. Rohmaniyah, and C. Lundry "Getting Culture: A New Path for Indonesia's Islamist Justice and Prosperity Party?," Contemporary Islam, Feb. 2012, p. 1-17. The combination of Wahhabi puritanism and Muslim Brotherhood activism was an outgrowth of the flight of Muslim Brotherhood intellectuals to Saudi 
these differences are that the PPMWI variant of Wahhabism embraces religious and cultural diversity.

Kyai Fata Mu'min was actively involved in inter-faith dialog and in conversations with other Muslim leaders. Early in 2011 he explained that based on his study of "world religions" he could find good in all of them. PPMWI also rejects the position that there is a link between Wahhabi religious teachings and violence. Writing in the pesantren's in house magazine Buletin Wathoni, Kyai Ahmad Janan Asifudin stated:

PPMWI has used Fath al-Majid as a basic work for a long time. The reason is not that PPMWI is fanatical or blindly follows the teachings of Muhammad bin Abdul Wahab. .... It is because in Fath al-Majid that we find examples of the ways in which the Prophet and his companions practiced taw hid, whereas other works are theoretical, approaching it from the standpoint of theology or philosophy. In other words, theoretical discussions of tawhid are important, but we cannot stop with theory. Fath al-Majid includes only selections from the Qur'an and badith and exegesis concerning the nature of tawbid. This is very far from the terrorist agenda. People who say that Fath al-Majid promotes terrorism definitely do not understand its content or have not yet read it carefully enough. We do not study Muhammad bin Abdul Wahab's political activities. That is another matter. ${ }^{25}$

This discussion of Fath al-Majid clarifies important elements of the pesantren's social identity. It is illustrative of the ways in which PPMWII distinguishes between religion and politics. It is al-Wahhab's theology and not his politics that is fundamental. Kyai Ahmad comments on culture in the same article. He states that Islam is not "anti-culture" and that only those aspects of culture in conflict with religious teachings should be rejected and that others should be supported. He refers to the Quranic injunction to al-'amr bi'-ma'ruf wa naby 'an-l-munkar is (command the good

Arabia from other Middle Eastern countries to avoid persecution beginning in the 1950s. It gave rise to politically militant forms of Wahhabism including the Sahwa movement in Saudi Arabia and has contributed to shaping Islamist ideologies in Indonesia and elsewhere in Southeast Asia. T. Hegghammer and S. Lacroix "Rejectionist Islamism in Saudi Arabia: The Story of Juhayman al-Utaybi Revisited," International Journal of Middle East Studies, vol. 39,2007, pp. 103-122.

25 "InovasiVisi Yayasan Pomesmawi/PPMWI dan Beberapa KenyataanTantangan di Lapangan (Catatan dari Pertemuan Tg. 29 Juni 2010," Buletin Wathoni, September 2010. 
and forbid the evil) a proposition that few Muslims would disagree with. ${ }^{26}$ Questions about what exactly are the good that Muslims are obligated to command and the evils they must forbid and how to balance these principles are, however, topics of contentious debate. In general PPMWII emphasizes commanding the good as a strategy for establishing moral order. He concludes by stating that abandoning culture would impoverish the Muslim community. This affirms the importance of culture in the construction of the pesantren's identity and differentiates it from other Indonesian groups that combine Wahhabi theology with the rejection of local culture.

PPMWII maintains a clear separation between secular and religious subjects. While the religious curriculum is fixed, secular instruction changes in correspondence with educational needs. Secular subjects are, however, understood as being religious in the ultimate sense for two reasons. The first is that all knowledge originates with God. The second is that knowledge of creation is also knowledge of God. This eliminates concern about the "Islamicization of knowledge" evident in some Indonesian Muslim schools and pervasive in neighboring Malaysia. ${ }^{27}$ There is no need to "Islamicize" what is by definition Islamic. PPMWI is globally oriented and has placed graduates at prestigious secular universities in the United States and Canada, equally prestigious Muslim universities in Egypt and Saudi Arabia as well as secular and Islamic universities in Indonesia. Few graduates become religious scholars. Most find employment in the private or public sector. They include construction workers, teachers, engineers, shopkeepers, lawyers, computer specialists, research biologists, civil servants, university professors and entrepreneurs, to name few. There is very little, other than distinctive understandings of tawhid that distinguishes them from other Indonesian Muslims. Many students are not fully aware of the "Wahhabi" foundations of their religious education. Several alumnae interviewed in 2012 could not remember the title, much less the sectarian orientation, of Fath alMajid. Most, but not all, come to accept this understanding of Islam but do not think of themselves as "Wahhabis" in the way that the term is

${ }^{26}$ See Qur'an (3:110).

${ }^{27}$ On debates concerning the "Islamization of knowledge" in Malaysia see: M. Abaza, Debates on Islam and Knowledge in Malaysia and Egypt: Shifting Worlds (London: Routledge, 2002), pp. 86-105. 
commonly used in the West and in Indonesia. In general PPMWI and the community it sustains is, in a sociological sense, everything that Roy's "New Global Ummah" is not.

\section{PPMWI and the Construction of Social Identity}

Pesantren education involves more than the transmission of knowledge. It seeks to inculcate religious values as the basis of a type personal identity Smith and Woodward have described as the "pesantren self" and to establish and maintain what Durkheim called a "moral community" both of which are based on student/teacher bonds and shared religious knowledge acquired through the pesantren experience. ${ }^{28}$ This community, the social relations and religious principles on which it is based, is constitutive and regulatory. It provides both a sense of community and a moral compass. The pesantren self is what Mead terms a "me," an integrated personality defined in reference to the "generalized other" of the pesantren moral community and differentiated from individual and collective others. ${ }^{29}$

Tawhid is the defining characteristic of PPMWI identity. When asked to speak about the pesantren's core values, faculty, students and alumnae nearly always describe it as the most important. Others include nationalism, pluralism, Javanese culture, non-violence and gender equity. These values are inculcated through formal education, study groups devoted to religious topics and communal life and ritual performance. The construction of PPMWI is a directed process, guided by the kyai family.

Wisuda, a secular ritual, combines all of elements. Its purpose is to mark and accomplish the transition from student to alumnae and to reinforce the solidarity of the moral community. This is accomplished through the incorporation of indexical symbols that point towards the defining characteristics of PPMWI identity into a performative core based on what was originally a Western secular rite of passage.

${ }^{28}$ On these concepts see L. Tole, "Durkheim on Religion and Moral Community in Modernity," Sociological Inquiry, vol. 63, No.1, 1993, p. 1-29 and B. Smith, And M. Woodward, "De-colonizing Islam and Muslim Feminism" in B. Smith and M. Woodward (eds), Re-orienting Muslim Gender: Leaders, Feminists, Sufis and Pesantren Selves in Indonesia (London: Routledge in press, 2013).

${ }^{29}$ G. H. Mead, Mind, Self and Society from the Standpoint of a Social Behaviorist (Chicago: University of Chicago Press, 1956), p. 158. 
Moore and Myerhoff broke new ground in the study of ritual by calling attention to the ways in which what Turner calls "the ritual process" is not restricted to religion. They observe ritual need not take religious cosmology as a point of reference. They argue that theoretical approaches developed for the study of religious ritual can be used in the analysis of secular performances and that in both secular and religious settings ritual is among the means through which social order is established and maintained. In many modern secular societies as well as in traditional religious ones, ritual is among the means through which social identities are constructed. Graduation ceremonies are among the most common secular rituals and can be found in almost all modern societies.

Moore and Myerhoff also point to the fact that while ritual generally has a stable purpose it also "alludes to more than it says." ${ }^{30} \mathrm{To}$ elucidate the nature of these symbolic allusions we rely on Stanley Tambiah's application of Pierce's concept of "duplex structures" to the analysis of ritual symbols. This construct enables us to explain the localization and Islamicization of graduation ceremonies and their use as vehicles for communicating the ideological and theological synthesis on which PPMWI identity is based.

Tambiah builds on Pierce's concept of duplex structures to explain the interplay of continuity and change in ritual performance. Tambiah applies this approach in his analysis of relationships between political, religious and social dimensions of ritual. The same line of reasoning is can be employed in the analysis of the localization of global secular performance events, including graduations. Indexical symbols are among the duplex structures included Pierce's semiological system. ${ }^{31}$ Indexical symbols are signs that may be interpreted simultaneously as symbols that communicate universal meanings and as indexes standing in existential pragmatic relationship with the objects they represent. The "symbolic" half of an indexical symbol conveys abstract meaning. Its "indexical" component links that meaning with a particular person, group, or social

${ }^{30}$ S. Moore and B. Myerhoff, Secular Ritual (Assen: von Gorcum, 1977), pp. 3-24, 5 .

${ }^{31}$ S. Tambiah, Culture, Thought, and Social Action: An Anthropological Perspective (Cambridge: Harvard University Press, 1985), p. 132-168. On Pierce's theory of duplex structures see: G. Deledalle, S. Charles, Peirce's Philosophy of Signs: Essays in Comparative Semiotics (Bloomington: Indiana University Press, 2000), pp. 120-127. 
role. Tambiah argues that the use of indexical symbols in religious ritual modulates the interplay of systems of belief, that is, intellectual systems concerned with universals, with pragmatic dimensions of social life. Woodward shows that in Java they are used to establish royal authority by linking the Sultan and the palace with highly valued modes of Muslim religious practice including the veneration of the Prophet Muhammad. Here we show how the deployment of indexical symbols in secular ritual can be used to establish connections between global and local concepts and institutions in ways that aid in the construction of seamless identities - in this case a community and individuals who see themselves as modern, educated Javanese Indonesian Muslims who define relationships between humanity and divinity in terms of al-Wahhab's interpretation of tawhid.

\section{E. Wisuda at PPMWI: Rites of Passage and Indexical Symbols}

$W$ isuda or Western style graduation ceremonies have become an important part of Indonesian educational culture. Graduates from preschool to graduate school levels don caps and gowns to receive official recognition of their accomplishments and then pose for photos with family and friends to memorialize them. There is nothing exceptional about a pesantren staging graduation exercises. In 2012 PPPWI held its wisuda on 24 June. In most respects, there was nothing remarkable about it. Other Indonesians and people from diverse cultures across the globe would have seen it as just another graduation that only participants would find particularly interesting. The unremarkable character of this event is, however, an example of the way in which Wahhabi religious teachings can be integrated into cultural and social formations very different from those generally associated with "Wahhabism."

Graduations are rites of passage. They mark the transition for being a student to the next stage of life, whatever that may be. Victor Turner has observed that rites of passage typically include three distinct phases: separation, in which previously existing social bonds are dissolved, flowed by a period of liminality in which initiates receive instruction, and reintegration where they assume new social roles. For Turner, the liminal period is the most significant of the three. He observes that during this period status distinctions are dissolved; that initiates often wear costumes that mask personal identities. In the final phase they symbolically take 
up a new set of social roles and responsibilities. The PPMWII wisuda follows this pattern in most respects, the exception being that gender distinctions are maintained in the liminal period.

The separation phase begins with the construction of a ritual space in the courtyard in front of the pesantren mosque. This involves the erection of a canopy, the installation of a temporary stage and a public address system and the placement of chairs. It concludes with santri wearing graduation regalia, faculty, family and guests enter and assume their positions. The pesantren drum band performs at this point. Santri wear trans-national academic regalia including caps and gowns recognizable as "graduation attire" nearly anywhere. As is similar ceremonies across the country, female graduates wear headscarves (jilbab) underneath their caps. They are seated facing the stage. Family and guests sit behind them. Faculty do not wear academic regalia, but the same types of clothing they usually do in the conduct of their responsibilities at the pesantren. Parents and other guests wear varied styles appropriate for ceremonial occasions. Some men wear suites and ties typically associated with modernist Islam, others trousers and "Muslim" shirts and still others sarong and "Muslim" shirts associated with traditional Islam. Women wear either Javanese batik or contemporary Indonesian "Muslim" fashion. ${ }^{32}$ All women wear headscarves and none wear niqab. Younger students wearing pesantren uniforms crowd around the borders of the ritual space. The contrast between uniformed santri and adults in normal attire symbolizes the distinction between santri and alumnae with the soon to be graduates occupying an intermediate, liminal position.

The liminal phase was marked by speeches in which students were congratulated on their accomplishments and admonished to live moral and productive lives and the presentation of diplomas. Each student shook hands with school leaders as she or he received a diploma, known in Indonesia by the Arabic term ijazab. ${ }^{33}$ There were also awards and a

32 Suites and ties have been associated with Muhammadiyah since the early 20th century. Sarong and long tailed, collarless shirts are associated with NU. On contemporary Indonesian Muslim fashion see E. Amrullah, "Indonesian Fashion Styles and Designs," ISIM Review, vol. 22, no. 1, 2008, pp. 22-25.

${ }^{33}$ The use of the term ijazah as a translation for diploma establishes a correspondence between western and traditional Islamic education. An ijazah, in the traditional sense, is not the same as a diploma. It does not indicate completion of a 
musical performance. Proud parents and friends snapped photos with cameras and hand phones and there were professional video shooting teams. This is the ritual core of school graduation and is almost the same wherever it is found, though the combination of academic caps and headscarves is less common in Western countries than in Indonesia.

The reintegration phase consist of an address by the director of the PPMWI Madrasah Aliyah who spoke in terms remarkably similar to those Turner used in his theoretical discussion of rites of passage. He told the new graduates that they were no longer santri (students) at the pesantren and had become members of the family of alumnae. In Indonesia this social role is more important than in many Western societies. Graduates of secular schools, as well as pesantren, continue to define themselves in terms of ties with the schools they attended. There is a formal PPMWI alumnae group, but informal ties are more significant. Many alumnae send their children to the pesantren for the same combination of religious and secular education they received. Many contribute financially and visit either the pesantren itself, or members of the kyai family on Lebaran (Id alFitri) at the end of the fasting month of Ramadan, or at times when they are in need of spiritual guidance or counseling. For PPMWII graduates, the pesantren is especially significant as a source of collective identity because it is the center of a small and distinct religious community.

\section{Indexical Symbols}

Indexical symbols included in wisuda at PPMWII link the ritual core emphasizing the place of the pesantren in the global system of academic degrees and titles to local religious, cultural and political discourse systems and social-cultural practice. There were no explicit references to tawhil other than an admonition to avoid shirk (associating other beings and powers with God) that is the opposite of tawhid in a speech by one of the teachers. Further symbolic references to this concept were not required because it is central to the community's identity. There were five sets of indexical symbols linking the wisuda to sacred space, concepts of gender relations, the nexus of Islam, nationalism, globalism and culture course of study, but rather mastery of a particular religious text, and authority to teach it. It places the recipient in a line of teachers and students, while a diploma certifies that the recipient has completed a course of study defined by an institution. In Indonesia ijazab refers to both modes of accreditation. 
that defines the pesantren's educational agenda, the moral community including the kyai family, students and alumnae and Indonesian Muslim youth culture.

\section{Sacred Space}

The wisuda is held in a space also used for congregational prayers on Muslim holy days. The mosque is hidden from view during the wisuda, but is present in the memories of participants. It presence lends an aura of sacristy to an ostensively secular event as the Muslim moral community defined by the pesantren assembles for a secular ritual that carries it forward in time. The Muslim salutation Assalämu alaikum wa-Rahmatullähi waBarakatuh (Peace be unto you and so may the mercy and blessing of God) is recited at the beginning of every speech. This is common practice at public events, even those that are not explicitly religious. Together these elements of wisuda locate it in a Muslim geographic, social and discursive space particular to PPMWI.

\section{Gender}

As is generally true in Muslim contexts, sacred space is gendered. It is characterized by shari ${ }^{\prime} a h$ based gender separation as understood at PPMWI. Males and females are seated separately on either side of an aisle in full view of one another. Both male and female students received their ijazah from and shook hands with male teachers. The Master of Ceremonies was a young woman. Musical performances and the valedictory addresses were also by gender integrated groups. Female and male students mixed freely and posed for photographs together after the ceremonies. This combination of gender segregation and inclusion is in keeping with daily practice at PPMWI. Male and female students sit on opposite sides of gender-integrated classrooms. The drum bands and even the karate club are gender inclusive. In contrast at the Saudi-Wahhabi oriented Imam Bukhari Madrasa there is total gender segregation with separate classrooms and even mosques for males and females. Virtually no contact between male and female students is allowed. Even in many NU oriented pesantren gender segregation is stricter than at PPMWII. Many have a common curriculum, but separate classes for male and female students who rarely encounter each other inside the pesantren. At 
Lirboyo, the only males allowed inside the walled women's quarters where female students live and study are teachers, fathers and brothers. In Saudi Arabia, education is completely segregated and there are restrictions on the subjects that female students can study. At PPMWI girls are actively encouraged to follow their own interests in the pursuit of both religious and secular knowledge.

\section{F. Islam, Nationalism, Globalization and Culture}

These themes are basic elements of the curriculum and culture of PPMWII. They articulated in valedictory addresses by high achieving graduates. There are four, one in each of the languages associated with these themes: Arabic, Indonesian, English and Javanese. Arabic is the language of Islam, Indonesian that of nationalism, English of globalization and Javanese of culture. They were delivered in that order. In 2012 he tone of the first three was formal and serious. The final address was humorous, in keeping with the style typical of pesantren. This is an important distinction within Javanese Muslim culture. Modernist and Islamist religious talks (pengajian) tend to be formal and serious, consisting of a combination of quotations from the Qur'an and badith and commentaries on them. While these elements are present in traditionalist discourse, it also uses combinations of stories, personal anecdotes and jokes to make religious points. Here again, the culture of PPMWII is closer to that of the traditional pesantren than to other Indonesian modernist and Salafi communities. Few in the audience and not all of the graduates understood the Arabic and English addresses. What is important is not so much the content, but rather the symbolic significance of the use of languages that point to communities and discourse systems beyond the borders of the pesantren community. The use of these linguistic conventions makes the point that the PPMWII moral community is engaged with and is a component of these larger systems.

\section{G. The Moral Community}

At the end of the reintegration phase of the wisuda graduates swear an oath to devote themselves to the principles of the pesantren. This marks the completion of their transformation from santri to alumnae and defines responsibilities associated with that identity: 
There is no God but God and Muhammad is the Messenger of God.

I accept the obligation to place absolute trust in God, the Lord of all creation.

I will not engage in contentious discourse that would divide the Muslim community, as this is clearly forbidden by God and his Prophet.

I accept the obligation to guard the honor and good name of the pesantren and to maintain relationships with it and the alumnae.

I accept the obligation to participate in the development of the pesantren and the nation as a whole through good deeds that God loves.

The oath begins with the shabada (confession of faith) that is the first of the five pillars of Islam. The second uses the Arabic term taqwa or absolute trust in God. This is a reference to the deep faith that the pesantren seeks to cultivate in santri and amplifies the first statement. The final three are more complex. The fourth statement speaks to issues of Muslim unity, and of avoiding conflict with other Muslims. This is an implicit disavowal of takfiri rhetoric. The fifth speaks of continued participation in the moral community defined by the pesantren. The final statement suggests a combination of loyalty to and support for both the pesantren and the nation through pious acts.

\section{H. Indonesian Muslim Youth Culture}

The wisuda concluded with a shalawat performance. Shalawat is a genre of sufi devotional music praising the Prophet Muhammad and his family. The denunciation of music, and especially sufi devotional music is characteristic of Saudi-Wahhabism and of Indonesian Muslim movements associated with it, but not PPMWII. Here, many musical genres including Indonesian and American pop as well as Islamic devotional music are part of daily life. A mixed gender duet accompanied by rabana (tambourines) performed Solatun Bi Salamin at the 2012 wisuda. It describes the Prophet Muhammad as having been a prophet prior to the moment of creation. This and many other shalawat are based on the sufi teachings of Ibn al Arabi (1165-1240) for whom tawhid led to the doctrine of the "unity of 
being" and the identification of the divine essence and the human soul. ${ }^{34}$ Nothing could be further from the PPMWII understanding of tawhid.

Shalawat has figured significantly in the religious lives of traditional Javanese Muslims for centuries. The Yogyakarta kraton (palace) has shalawat texts dating to the early eighteenth century. Shalawat is an almost daily practice in NU communities. Since 2005 it has entered the realm of Indonesian popular culture, largely due to the enormous popularity of the Javanese-Hadrami performer Habib Syech bin Abulkadir Assegaf. Habib Syech has achieved "rock star" status. His performances attract crowds as large as 300,000 most of them young people. His recordings are regularly played at mosques prior to evening prayers, and can be heard and purchased as shrines throughout Java, and as far away as Malaysia and Singapore.

Solatun Bi Salamin is his most popular recording. ${ }^{35}$ Many Indonesians say that "everyone" knows it. Because it is in Arabic, few understand the theological message of the lyrics. It has, however, become almost the "Muslim national anthem" of Indonesia. It goes without saying that most Wahhabi oriented Indonesians find the emergence of shalawat as a popular expression of Muslim piety to be disturbing, to say the least. PPMWII is an exception. Solatun Bi Salamin is accepted not because of its theological content but because it is a popular expression of Muslim piety - and a very good song.

Taken together the indexical symbols included in the wisuda express and are intended to contribute to the construction of personal and collective identities entirely different than those that the literature on Wahhabism, Salafism and the "New Global Ummah" would predict. Collectively they refer to a moral community rooted in Abd al-Wahhab's understanding of tawhid that is inclusivist, nationalist and deeply rooted in Indonesian and Javanese Muslim cultures.

\section{Conclusions: Reflections on Identity, Theology and Violence}

PPMWI is a particularly significant case for testing the hypothesis set

${ }^{34}$ On Ibn al-Arabi see W. Chittick, The Sufi Path of Knowledge Ibn al-Arabi's Metaphysics of Imagination (Albany: State University of New York Press, 1989), pp. 15-28 and on the role of his teachings in Southeast Asian Islam, M. Woodward, Java, Indonesia and Islam (New York: Springer 2010, pp. 137-167.

35 http:/ / www.youtube.com/watch?v=BdEy2ew1MSw 
out at the beginning of this paper according to which there is not a causal relationship between basic religious orientations, such as al-Wahhab's interpretation of tawhid, and social and political action. PPMWI embraces these religious teachings. They are central to its collective identity. This does not, however, lead to the construction of socially or politically exclusivist let alone violent identities as primordialist understandings of Wahhabism current in Western and Indonesian discourse suggest. Indeed opposition to religious and political violence and support secular Indonesian nationalism are also essential elements of PPMII identities. This indicates that there is not a "primordial" Wahhabi identity as polemic literature in Indonesian and western languages suggests. The claim that there is should be taken as an example of "everyday primordialism."

There are many other examples that indicate that religion serves to legitimate social and political action, but that basic religious teachings do not lead to particular forms of social or political action. In Indonesia, there are Muslim groups, including the Front Pembela Islam (FPI, Front for the Defense of Islam) rooted in supposedly peaceful sufi theologies that advocate and engage in violence against those it terms "theological deviants." Tambiah has shown that Theravada Buddhism and Hinduism can be used to legitimize xenophobia, ethno-religious violence and state terrorism despite their doctrinal emphasis on non-violence. ${ }^{36}$ Roman Catholicism has been used to legitimize Mother Teresa' selfless devotion to ameliorating the suffering of the poorest of the poor, and the terrors of the Inquisition. Anabaptist Protestant Christianity motivated, mass slaughter during the 16th century wars of religion as well as Amish pacifism.

This leads us to conclude that core religious teachings shape but do not determine personal and collective identities. Core theological teachings are one, but only one, of the elements combined in the construction of social identities through a complex form of bricolage. Lévi-Strauss was less concerned with questions of power and domination than subsequent generations of French social scientists and philosophers, particularly Foucault who argues that the construction of knowledge is shaped by power relationships. Primordialism is all too often an element

${ }^{36}$ S. Tambiah, Ethnonationalist Conflicts and Collective Violence in South Asia (Berkeley: University of California Press, 1999), pp. 266-295. 
Inayah Rohmaniyah \& Mark Woodward

of contentious political discourse caste in the guise of scholarship. Promoting the idea that there are primordialist identities can a strategy for organizing difference in ways that justify conflict. 


\section{BIBLIOGRAPHY}

Abaza, M., Debates on Islam and Knowledge in Malaysia and Egypt. Shifting Worlds, London: Routledge, 2002.

Abdullah, T., Schools and Politics. The Kaum Movement in West Sumatra (19271933), Ithaca: Cornell University Press, 1971.

Amrullah, E., "Indonesian Fashion Styles and Designs," ISIM Review, vol. 22, no. 1, 2008 p. 22-25.

Assyaukanie, L., Islam and the Secular State in Indonesia, Singapore: Institute for Southeast Asian Studies, 2009.

Barth, F., Ethnic Groups and Boundaries. The Organization of Culture Difference, Long Grove: 1998.

Barton, G. and Fealy, G. (eds), Nadblatul Ulama, Traditional Islam and Modernity in Indonesia, Clayton: Monash Asia Institute, 1996, p. 1-270.

Bruinessen, M. van, "Traditionalist and Islamist Pesantren in Contemporary Indonesia," in Noor, F., Y. Sikand and M. Van Bruinessen (eds), The Madrasa in Asia. Political Activism and Transnational Linkages, Amsterdam: University of Amsterdam Press, 2009, p. 217-247.

Chittick, W., The Sufi Path of Knowledge. Ibn al-Arabi's Metaphysics of Imagination, Albany: State University of New York Press, 1989.

Cook, M., Commanding Right and Forbidding Wrong in Islamic Thought, Cambridge: Cambridge University Press, 2001.

De Long-Bas, N., Wahhabi Islam. From Revival and Reform to Global Jihad, New York: Oxford University Press, 2004.

Deledalle, G., S. Charles, Peirce's Philosophy of Signs. Essays in Comparative Semiotics, Bloomington: Indiana University Press, 2000.

Dhofier, Z., "Kinship and Marriage among the Javanese Kyai," Indonesia, vol. 29, 1980, p. 47-58.

----, The Pesantren Tradition. The Role of the Kyai in the Maintenance of Traditional Islam in Java, Tempe: Arizona State University Program for Southeast Asian Studies Monograph Series, 1999.

Fearon, D. and D, Laitin, "Violence and the Social Construction of Ethnic Identity," International Organization, vol. 54, no. 4, Autumn 2000 , p. $845-877$. 
Gade, A., "Sunan Ampel of the Javanese Wali Songo" in Renard, J., Tales of God's Friends: Islamic Hagiography in Translation, Berkeley: University of California Press, 2009, p. 341-358.

Geertz, C., Islam Observed. Religious Development in Morocco and Indonesia, Chicago: University of Chicago Press, 1971.

Gold, D., Hatred's Kingdom: How Saudi Arabia Supports the New Global Terror, Washington DC: Regency Publishing, 2003.

Hasim, R., Educational Dualism in Malaysia. Implications for Theory and Practice, Kuala Lumpur: Oxford University Press, 1996.

Hefner, R. (ed.), Making Modern Muslims. The Politics of Education in Southeast Asia, Honolulu: University of Hawai'i Press, 2009.

Hegghammer, T., S. Lacroix "Rejectionist Islamism in Saudi Arabia: The Story of Juhayman al-Utaybi Revisited," International Journal of Middle East Studies, vol. 39, 2007, p. 103-122.

Jenkins, R., Social Identities, London: Routledge, 2004.

Lehman, F., "Kayah Society as a Function of the Shan-Burmese-Karen Context," in Steward, J. (ed.), Contemporary Change in Traditional Societies, volume I, Urbana: University of Illinois Press, 1967, pp. 1-104.

Lukens-Bull, R.A., A Peaceful Jihad. Negotiating Identity and Modernity in Muslim Java, New York: Palgrave Macmillan, 2005.

Mead, G. H., Mind, Self and Society from the Standpoint of a Social Behaviorist, Chicago: University of Chicago Press, 1956.

Moore, S. and B. Myerhoff, Secular Ritual, Assen: von Gorcum, 1977.

Nakamura, M., The Crescent Rises Over the Banyan Tree. A Study for the Muhammadiyah Movement in an Indonesian Town, Athens: Ohio University Press, 1983.

Neil, R. van, The Emergence of the Modern Indonesian Elite, The Hague: W. van Hoeve, 1960.

Noer, D., The Modernist Muslim Movement in Indonesia 1900-1942, Oxford: Oxford University Press, 1973.

Peacock, J., Muslim Puritans. Reformist Psychology in Southeast Asia, Berkeley: University of California Press, 1978. 
Pohl, F., Islamic Education and the Public Sphere. Today's Pesantren in Indonesia, Bonn: WaxmannVerlag GmbH, 2009.

Saidiman, “The Wahhabis Inferiority," Jaringan Islam Liberal, http:// islamlib.com/en/article/the-wahhabis-inferiority, date access 26 March 2010.

Smith, B., And M. Woodward, "De-colonizing Islam and Muslim Feminism" in B. Smith and M. Woodward (eds), Re-orienting Muslim Gender: Leaders, Feminists, Sufis and Pesantren Selves in Indonesia, London: Routledge in press, 2013.

Sperber D., Rethinking Symbolism, Cambridge: Cambridge University Press, 1975.

Strauss, C. Levi, The Savage Mind, Chicago: University of Chicago Press, 1966.

Tambiah, S., Culture, Thought, and Social Action. An Anthropological Perspective, Cambridge: Harvard University Press, 1985.

----, Ethnonationalist Conflicts and Collective Violence in South Asia, Berkeley: University of California Press, 1999.

Tole, L., "Durkheim on Religion and Moral Community in Modernity," Sociological Inquiry, vol. 63, No.1, 1993, p. 1-29.

Wahid, A. (ed.), Ilusi Negara Islam. Expansi Gerakan Islam Transnasional di Indonesia, Jakarta: LibForAll Foundation, 2009, p. 59-132.

Woodward, M., Java, Indonesia and Islam, New York: Springer, 2011.

----, A. Amin, I. Rohmaniyah and D. Coleman, "Muslim Education, Celebrating Islam and Having Fun as Counter-Radicalization Strategies in Indonesia," Perspectives on Terrorism, vol. 4, no. 4, 2010, p. $28-50$.

----, M., A. Amin , I. Rohmaniyah, and C. Lundry "Getting Culture: A New Path for Indonesia's Islamist Justice and Prosperity Party?," Contemporary Islam, Feb. 2012, p. 1-17. 
Inayah Rohmaniyah \& Mark Woodward 